OP-169

精索静脈痼と身長、体重、body mass index との関連について

\section{独立行政法人国立病院機構災害医療センター泌尿器科 ${ }^{11}$, 昭和大学医学部泌尿器科 ${ }^{2)}$ \\ 坂本 英雄 ${ }^{11}$, 佐藤 直也 ${ }^{17}$, 石原 理裕 ${ }^{13}$, 檜垣 昌夫 ${ }^{11}$, \\ 小川 良雄 ${ }^{2}$}

【目的】精索静脈瘤は思春期以後に発生頻度が増加し、精索静脈瘤の 出現と体型との関連が示唆されている。今回、成人男性で精索静脈 瘤と身長、体重、body mass index (BMI) との関連について検討し た。【方法】不妊症を主訴に受診した993名と除囊部症状を主訴に受 診した 56 例の計 1049 例（平均年齢 34.7 歳）を対象とした。精索静 脈瘤の診断は理学的検査で行った。BMI [計算式 $=$ 体重 $(\mathrm{kg}) /$ 身長 (m) $\left.{ }^{2}\right]$ により $20 \mathrm{~kg} / \mathrm{m}^{2}$ 末満 (111 例)、20-25 kg/m $\mathrm{m}^{2}$ (681 例)、25$30 \mathrm{~kg} / \mathrm{m}^{2}$ (238 例)、 $30 \mathrm{~kg} / \mathrm{m}^{2}$ 以上(19 例)の 4 群に分類した。【結果】 297 例に精索静脈瘤を認め、精索静脈瘤群と非精索静脈瘤群の間に 身長（各々 $1.72 \mathrm{~m}$ vs. $1.7 \mathrm{~m} 、 \mathrm{p}=0.0069$ ）、体重（各々 $67.2 \mathrm{~kg}$ vs. 68.2 $\mathrm{kg} 、 \mathrm{p}=0.0235$ )、BMI（各々 $22.7 \mathrm{~kg} / \mathrm{m}^{2}$ vs. $23.5 \mathrm{~kg} / \mathrm{m}^{2} 、 \mathrm{p}<0.0001$ ) に 差がみられた。一方、 $20 \mathrm{~kg} / \mathrm{m}^{2}$ 末満、20-25 kg/m² $25-30 \mathrm{~kg} / \mathrm{m}^{2} 、 30$ $\mathrm{kg} / \mathrm{m}^{2}$ 以上の各群の精索静脈瘤の発生頻度は各々 $36.9 \%$ (41 例)、 $30.3 \%$ (206 例)、 $20.2 \%$ (48 例)、10.5\% (2 例) と BMI の低い群で 精索静脈瘤の発生頻度が高かった $(\mathrm{p}=0.0011)$ 。Grade 別に非精索静 脈瘤群と身長、体重、BMI を比較すると Grade3 症例のみに有意差 がみられた。また、Grade2、3 精索静脈瘤では BMI の低い群で有意 に発生頻度が高かった。結諭]精索静脈瘤、特にGrade3 精索静脈瘤 の出現と身長、体重、BMIの間に関連がみられた。

\section{OP -170}

不妊を伴う停留精巣に対する治療の検討

\section{神戸大学大学院医学研究科腎泌尿器科学分野}

千葉 公嗣, 石川 智基, 山口 耕平, 武中 篤, 藤澤 正人 (目的)停留精巣は通常、検診により発見され、小児期に治療 されていることが多い。しかし、男性不妊を主訴に受診し、 停留精巣と精液所見の異常を指摘される患者も存在し、不妊 治療としての精巣固定術、TESEに関して未だコンセンサス が得られていない。(対象) 1990 年以降不妊を主訴に当科を 受診し、停留精巣を認めた 20 例。(結果) 年齢は 30.8 (23〜38) 歳、全例に精巣固定術を施行。術前精单容積は停留精巣側 7.0 cc、健側 $17.4 \mathrm{cc}(\mathrm{p}<0.001)$ 。Johnsen score は停留精巣側 2.2、 健側 6.6。両側停留精巣は 10 例で、全例無精子症、うち 2 例に 片側摘除反対側固定を行い、1 例に seminoma 認めた。片 側停留精巣は 10 例で、 5 例無精子症、3 例乏精子症、 2 例精 液所見正常であった。両側例、片側例で術前血中 FSH 值 $31.9,16.5(\mathrm{ng} / \mathrm{ml}, \mathrm{p}<0.01) 、 \mathrm{LH}$ 值 $10.9,7.1(\mathrm{ng} / \mathrm{ml}, \mathrm{p}<0.05)$ 、 $\mathrm{T}$ 值 3.5.5.0 (ng/ml, p < 0.05) と有意差を認めた。固定術と 同時にTESEを 9 例に施行し、両側例 4 例は全例精子回収 できず、片側例 5 例は全例健側から精子回収できた。術後観 察期間は $26.4(1 \sim 132)$ 力月で、術前無精子症で射出精子が 出現した症例はなかった。固定術後の TESE は 1 例のみ 10 カ月後に施行し、精子回収できなかった。術前乏精子症の片 側例で術後自然妊娠を 1 例認めた。(結論) 無精子症を伴う両 側停留精巣の妊孕性は非常に低いといわざるをえない。

\section{OP-171 造精機能におけるアミノ酸の役割}

\section{浜松医科大学泌尿器科学 \\ 寺田 央巳, 原田 雅樹, 麦谷 荘一, 大園 誠一郎}

目的：アミノ酸は化学的に合成するとL-アミノ酸とその光 学異性体であるDアミノ酸が $1: 1$ のセラミ混合物として得 られる。一方、生体内ではLーアミノ酸だけが見いだされる。 近年、高感度な光学分割法の進歩により D 型のアミノ酸が 遊離型もしくはタンパク質、ペプチドと結合した形で生物界 に多量に存在することが明らかとなった。中でも遊離型の serine, threonine, aspartic acid などの D 型が注目されてい る。今回我々は無精子症症例と正常精子症例におけるアミノ 酸の解析を行ない、TESEによって得られた組織標本の病理 組織学的診断結果と対比して報告する。結果：アミノ酸分析 の結果においては、非閉塞性無精子症で $\mathrm{L}$ 型 aspartic acid 值が有意に上昇を示した。一方、D-アミノ酸は serine, aspartic acidの存在が正常精子症例で示唆された。病理組織学的 検査は Johnsen's score count (JSC) で行った。結果的に JSC が低い症例では L-threonine 值の有意な低下が認められた。 考察： aspartic acidは paracrine 分泌され Leidig cell の testosterone 分泌を促進するといわれそれが feed back されて 精子成熟に関わるといわれ、D aspartic acid は elongated spermatidに存在するといわれている。結語：今後、造精機 能に関与する D 型アミノ酸の役割について精漿、精巣組織 および血中アミノ酸値を比較し検討を加え報告する。

\section{OP-172 Effects of sildenafil on sperm hyperacti- vation}

\author{
鳥取大学医学部腎泌尿器学 \\ ツナピ パナヨタ,ディミトリアディス フォティオス, \\ ソフィキティス ニコラオス,宮川 征男
}

【Objectives】 We evaluated the role of sildenafil (SL) in sperm hyperactivation assay (SHA) outcome. IMaterials and Methods】 Each of 15 asthenospermic men produced 3 semen samples. Each sample was processed for swim-up procedure and then the recovered fraction of motile spermatozoa was incubated for 8 hours at $37^{\circ} \mathrm{C}$ under $5 \% \mathrm{CO}_{2}$ in air. Then the \% of hyperactivated spermatozoa was calculated using a computer-assisted sperm hyperactivation assay system. The patients were then administered $50 \mathrm{mg}$ SL daily for 10 weeks. Then 3 semen samples were collected from each patient. Semen samples were processed for the same swim-up procedure, and the \% of hyperactivated spermatozoa was calculated again. 【Results】 The \% of hyperactivated spermatozoa was significantly larger after SL administration $(7.4 \pm 1.1)$ than prior to it $(5.0 \pm 1.2)$ $(\mathrm{p}<0.05)$. 【Conclusions】 Since sperm hyperactivation is required for the spermatozoon fertilization ability, the increase in the outcome of SHA after SL administration suggests that spermatozoa collected after SL treatment may have higher fertilizing capacity. 